\title{
"Man" and His "Others"
}

\section{Ellen T. Armour}

Those of us who trade in contemporary French philosophy are supposed to be able, at the drop of a hat, to tick off the various symptoms of modernism's demise: the death of the subject, of credible metanarratives, of reason and truth. We encounter this expectation because many of those figures whom we study and deploy are supposedly caught up in the wide net cast by the postmodern. Yet most of us would follow many of these figures and greet pronouncements that "we" are done with modernity with great skepticism-and rightly so.

However, a case can certainly be made (as many of these same contemporary French philosophers and cultural critics do) that we have come to occupy a distinctive relationship toward certain impulses, notions, concepts, and ways of being that in some sense can be characterized as "modern." I want to make a case here for this sense of postmodernity. To borrow a figure from the later Heidegger, could one signpost of modernity be a "fourfold" made up of man, his raced and sexed others, his divine other, his animal other-placed in a certain configuration? In this configuration, man occupies the center, while his others surround him like a network of mirrors that reflect him back to himself, thus securing his boundaries. A distinctive relationship to death, desire and embodiment (among other things, including time and being, arguably) links and separates one from the other. It is this configuration-perhaps even this fourfold-that is disintegrating in our time. And we are struggling to bear (in the sense of carry and bring to birth) whatever will take its place. 


\section{ELLEN T. ARMOUR}

I am particularly interested in the roles played by religion and by sexual and racial differences in the constitution and sustenance of this fourfold, in its passing away, and in whatever will come to replace it. Fully describing this fourfold is beyond the scope of this paper, as is the laying out the trajectory of its emergence. But familiarity with any of the epochal narratives that describe the shift from medieval notions of order and authority to modern notions of the same should suffice to sketch its outlines in broad strokes. One can think, for example, of the displacement of Christian authorities by the authority of autonomous scientific reason as signaling the emergence of man as modernity's centerpiece. The emergence of new taxonomies of nature and the sciences that attempt to fix them in place is part of that narrative. These include certain taxonomies of human beings-racial and sexual-that call upon "nature" as their guarantor and that are shored up by science and pseudo-science. (Here, I am thinking of the pseudosciences of race from phrenology to The Bell Curve and those of sex, including the mad dash to identify a genetic cause for homosexuality.) It may go without saying — but shouldn't — that these cultural shifts have had profound material effects in the circulation of capital (financial, psychic, fleshly) via individual and social identities constructed by force, by discipline, by the circulation of capital itself.

Religion, racial and sexual differences are at once participants in and victims of this epochal shift. Christian theology and philosophy of religion still bear the marks of the constraints imposed on religion by shifting notions of authority. That legacy can be read in the division between faith and reason, the equation of religion with morality, the emergence of fundamentalism, etc. The genesis of the field of religious studies (which takes a descriptive rather than prescriptive approach to religious diversity) lies within the development of new human taxonomies and capitals. Similarly, the very categories of racial and sexual difference within which most of us have come to take up our places are products of this modern era - as are the particular forms of racism, ethnocentrism, sexism, and heterosexism that are among the features of and impetuses behind their production.

What, then, leads me to suggest that this fourfold—or this version of it—might be passing away or disintegrating? Again, I can only be schematic. I described the modern configuration of the fourfold as a set of mirrors reflecting man back to himself and thereby securing him. Perhaps the fact that we can now see this configuration as a hall of mirrors signals modernity's passing. Man's others have provided a 


\section{'MAN' AND HIS ‘OTHERS'}

transcendental ground that made man possible. But we are coming to see that that ground is also transcendent in another way: each of man's others transcends man-in the sense of exceeding him and his mastery-and the boundaries of the four-fold. And perhaps it is that sense of transcendence that also provokes the disintegration that we are struggling to bear. The boundaries between man and his others are permeable; they leak. Movements for justice in the name of man's others (raced, sexed and animal) are arguably markers of that permeability. On the heels of permeability comes proliferation. Our canon of sexual identities has expanded to include transgendered, bisexual, as well as lesbian and gay - and that canon continues to expand. Race, too, proliferates and morphs. You will recall the debate as we geared up for the 2000 census over the categories for race, which were far too monolithic to capture complex and multiple lineages and identifications. Race, ethnicity and religion become intertwined here, as well, as those who attended a recent presentation on Arabs, Muslims and the census at the annual meeting of SPEP in October of 2004 learned. ${ }^{1}$

These events themselves signal the complex relationship between "post" and "modern." They depend very much on modern ideals, identities and institutions even as they transfigure and trouble them. And modern ideals can turn on those who would invoke them to new ends. Witness the impaling of affirmative action programs on the fencepost of presumptive equality. I worry about the rush to ground homosexuality in taxonomies of nature-especially genetics-given the developing science of genetic manipulation.

Things do not get any simpler when we turn to religion's place in our current cultural landscape. Predictions from Freud and others that, as modern man grew into his maturity, religion would go the way of the dinosaur have not materialized. Religion adapted to modernity. To some extent, modern versions of religion still predominate. Fundamentalisms-Christian and Islamic - are the products of modernity; direct or indirect reactions against its displacement of religious authorities and its excesses. But modern forms of religion also seem to be passing away. The so-called mainline Protestant denominations-themselves creations of modernity-are in decline. New kinds of churches (mega churches, but also smaller fringe churches of various constituencies) are taking their place. And religious pluralism, brought to consciousness by modernity, is no longer about those who live "out there" but is right here. Memphis, where I live, still has churches 


\section{ELLEN T. ARMOUR}

on every corner and synagogues in various sectors of the city, but now also boasts mosques, Hindu and Buddhist temples, etc.

In what follows, I will explore some of the more intriguing, if sometimes troubling, signs on our horizon in terms of this fourfold, importing resources from French and French-inflected philosophy in order to do so. What I will offer is at best an attempt to sketch out how one might use these resources to understand and intervene in that to which these signs bear witness. I will focus on one pole of the fourfold: the one that runs between man and animal. However, as I hope will become apparent, to focus on this pole is hardly to ignore the other poles of the fourfold; their traces will be visible. I am focusing on man/animal in part because it seems such a salient spot to start, given current events.

Let me mark this talk with three signposts: (1) I will call the first "War Images." The line between the animal and the human has been invoked in at least two places in the current wars: one of the Bush campaign's ads depicted the terrorists as a pack of wolves prowling the perimeter; and among the photos of prisoner abuse at Abu Ghraib is one depicting a prisoner positioned like a dog on a leash. (2) I will call the second signpost "Genetic Images." A recent cover of Time magazine reported the discovery of the God gene; a few years ago, the press similarly heralded the discovery of the so-called gay gene (both are highly problematic journalistic shorthand symbols to say the least). ${ }^{2}$ We could add to these images research into genetic causes of various diseases, the cloning of Dolly, the sheep, and now the first $\operatorname{dog}^{3}$ (3) This leads us to the third signpost, which I will call "The Life of Animals and Humanimals." In recent years, we have witnessed a proliferation of books, both fiction and nonfiction, that purport to get into the minds of animals. ${ }^{4}$ The market for such books has emerged as pets have become members of the bourgeois family replete with their own stores ("Petco, where the pets go"), gourmet bakeries, and day cares. As some animals seem to become more like humans, some humans are actively seeking to become more like animals. A documentary on the Discovery Health channel recently featured people who undergo extreme body modifications in order to physically resemble animals (I'm calling them humanimals): domestic cats, lizards, leopards. ${ }^{6}$

What do these images and events tell us about the fourfold? And what roles do religion, sexual and racial differences, play within them? What resources does French philosophy offer us as we attempt to parse these signs and wonders? Apart from the occasional passing 


\section{'MAN' AND HIS ‘O'THERS’}

reference to other philosophers, my focus here will be on an essay by Jacques Derrida entitled "The animal that therefore I am (more to follow)." This essay was originally delivered at a colloquium on Derrida's work held at Cerisy-la-Salle in 1997. I heard him give a version of it in the fall of 1998 at a seminar at New York University on animality. The topic of the ten-day colloquium at Cerisy, the autobiographical animal, was suggested by Derrida as the follow-up to two previous colloquia held at Cerisy on his work: on the Ends of Man (1980) and on Border Crossings (1992). This latest colloquium is linked to the first two: it queries the confines that purport to contain man by questioning the border that separates man and animal.

Derrida begins his essay by invoking an experience that, no doubt, many of us whose households include cats have had, but probably haven't thought about: what happens when your cat looks at you-naked-in the bathroom? For Derrida, at least, this experience is accompanied by shame, embarrassment-especially if the cat has a frontal view. Before whom or what is he ashamed? Animals, after all, are supposedly distinct from humans because they are not naked. More to the point, they don't know that they are naked; thus they are not ashamed. (The allusion to the story of the Garden of Eden in Genesis is intentional here and will become a theme later). Conversely, clothing is considered proper to the human. It is intrinsically connected to other distinctively human proper(ties): technicity, consciousness, and conscience. It is as though the abyssal gaze of his cat reflects Derrida back to himself as the 'man' that he is at least supposed to be. He writes: "the gaze called animal offers to my sight the abyssal limit of the human: the inhuman or the ahuman, the ends of man, that is to say the border crossing from which vantage man dares to announce himself to himself, thereby calling himself by the name that he believes he gives himself" (81).

This border between man and animal is first and foremost a linguistic site in several senses: language creates the border (man, Derrida says, "corrals all living things" under this one term, "animal" [397]) and does so by naming. Language is also what man has that he claims the animal lacks. Derrida coins a neologism to name this episteme: "l'animot." He writes, "Men would be first and foremost those living creatures who have given themselves the word that enables them to speak of the animal with a single voice and to designate it as the single being that remains without a response, without a word with which to respond" (397). 


\section{ELLEN T. ARMOUR}

This terrain, where man separates himself from the animal, is perhaps the founding site of philosophy, Derrida suggests, noting that philosophy seems to take for granted-and reinforces, for the most part-this fundamental division, at least on the surface. Exploring this site takes Derrida, as it does Giorgio Agamben, into the prephilosophical, if you will-that is, back to ancient religious myth. ${ }^{8}$ Both thinkers return to the creation stories in Genesis, each of which delineate man from animal via language. ${ }^{9}$ In the first story, God tells the first human couple (both the man and the woman, products of a simultaneous creation, are addressed here) to "fill the earth and subdue it; and have dominion over the fish of the sea and over the birds of the air and over every living thing that moves upon the earth" (Gen. 1.29, NRSV). In the second story, which is the more interesting to Derrida, God brings the animals to 'adam to be named. ${ }^{10}$ This god is not what Martin Heidegger would call the god of the philosophers-not Thomas Aquinas's immutable, impassable, all-knowing entity. This god seems finite; he waits to see what Adam will do-and seems not to know in advance. He wants to watch, to be surprised. Caught in the gaze of this god-caught gazing at this god-provokes in Derrida the same vertigo provoked by the gaze of his cat.

Another abyss also opens up here: the story of the naming of the animals occurs within the same mythological narrative that accounts for the origin of $\sin$. Derrida writes:

It is paradoxically on the basis of a fault or failing in man that the latter will be made a subject who is master of nature and of the animal. From within the pit of that lack, an eminent lack, a quite different lack from that he assigns to the animal, man installs or claims in a single movement what is proper to him (the peculiarity of a man whose property it is not to have anything that is exclusively his) and his superiority over what is called animal life. This last superiority, infinite and par excellence, has as its property the fact of being at one and the same time unconditional and sacrificial. (388)

This way of thinking about man —and about anima —-will prove foundational and difficult to shake. The possibility of the auto-biographical arises here, tied intrinsically to confession from Augustine to Rousseau and beyond with Descartes' ego cogito ego sum in the middle, "wait[ing] for us with his animal-machines" (389). This myth remains 
the mise-en-scène within which the so-called last philosopher of man, Martin Heidegger, thinks Dasein.

However, says Derrida, in the last 200 years, we have been living through a tectonic shift, of sorts, in man's relationship to the animal. Symptoms of this shift include the macroscopic and microscopic changes in what we call animal husbandry-incredibly efficient, deeply invasive technologies of animal breeding, feeding, slaughtering and processing that produce maximum pounds of tender meat at minimum price for human consumption; the use of animals in scientific research (the mapping of the human genome was preceded by maps of animal genomes); the usually unintended but no less dramatic animal "genocides" (Derrida's term, and its use is part of the problematic of the essay) from human damage to the environment and human attempts to repair the damage, and so on.

These changes produce reactions in the human body politic as well (the animal rights movement, People for the Ethical Treatment of Animals [PETA], the slow food/organic food movements, etc.). And they register at the philosophical level. Derrida recalls Jeremy Bentham's famous call to change the terms of the question regarding the line between human and animal. The question isn't whether animals know, think, speak, or respond (that is, are of the genus zoon logon echon), but rather: Do they suffer? The answer most of us would give (even if some might not see animal and human suffering as identical) is: yes. Derrida asks us to spend some time with this tectonic shift: thinking it through ungrounds the traditional discourse of man/animal. The very terms of the question shift from one of possessing (or not) certain powers/abilities to a question of passivity and powerlessness-impouvoir, if you will (the French captures the nuance better), of sufferance, of undergoing/going under. And our animal mirror, in this case, I think, shakes us up by reflecting that impouvoir that resides within us. The opposite of mastery, to be sure, that hallmark of modern subjectivity.

Derrida is not proposing here that there is no difference between man and animal after all; that would be to ignore the abyssal gaze with which the essay began. "The animal looks at us, and we are naked before it. Thinking perhaps begins there," he writes (374). But he does want us to ponder for a while- to stay with, as it were-the sympathy evoked in us by this brief recollection of these horrific tableaux. We are engaged in a war over pity; between those who acknowledge this experience of compassion (which, like sympathy, literally translates as "feeling-with") and those who don't. He wants us to think the abyssal 


\section{ELLEN T. ARMOUR}

border itself. There is no simple clean line separating "man" from "the wholly other that they call animal, for example, a cat" (380). Obscured by "l'animot" are the multiple differences within "the animal", "the living" - not to mention the multiple lines of continuity and discontinuity between "us" and "them."

With Derrida's meditations and provocations before me, I would like to return to the three signposts I marked at the outset: the war images (the photos from Abu Ghraib and the Bush campaign's ads depicting the terrorists as wolves), genetic mapping (the latest "news," via the popular press, in genetic research), and the lives of animals and humanimals. How might Derrida's insights help us understand these particular signs and wonders? What do these signs and wonders say back to Derrida?

Here is my overall thesis: all three confirm in different ways Derrida's insight that the border between man and animal is abyssal and multiple - and, I would add, fluid and fascinating (in the Latin sense of fasinans-magical and mesmerizing). What they say about our contemporary relationship to l'animot remains to be seen.

\section{The War Images}

Violence does not consist so much in injuring and annihilating persons as in interrupting their continuity, making them play roles in which they no longer recognize themselves, making them betray not only their own commitments but their own substance....[War] establishes an order from which no one can keep his distance; nothing henceforth is exterior. War does not manifest exteriority and the other as other, it destroys the identity of the same. ${ }^{11}$

-Emmanuel Levinas

The war images draw the line between man and animal, between "us" and "them." In the Bush campaign's ad, terrorists aren't humans with political and religious grievances, however unjustified (that is, meaning makers, responders), but cunning creatures who prowl at our borders waiting for a chance to prey upon us. I wonder whether the war of pity that Derrida describes as occurring around the animal applies here, too? Is it possible to feel sympathy for this enemy? A different relationship to death is invoked here, as well. These are "people" (or are they?) who would die as well as kill for their cause. In a recent essay, Judith Butler asks a propos of the war on terror, 9/11, 


\section{'MAN' AND HIS ‘OTHERS’}

and the liminal status of GLBT [Gay, Lesbian, $\mathrm{Bi}$, Transgendered] people in American society, what deaths are grievable? What lives are livable? Who is mourned, who is not? ${ }^{32}$

I have alluded to the modern taxonomies of race that funded racisms, colonialisms, and genocides of various sorts. Had we time, I would review with you arguments that I have made elsewhere using other texts of Derrida's, especially on Heidegger, about the role of the distinction between man and animal in those taxonomies. ${ }^{13}$ The war images call upon those taxonomies and their logic. The image of the naked soldier on a leash held by a female American soldier positions "them"--represented by a single Iraqi soldier (presumably Muslim) as liminal figures. ${ }^{14}$ The figure of the Iraqi prisoner evokes several borders: animal/human, domestic/savage, whiteness/otherness. She looks down at $\mathrm{bim}$ from the masterful end of the fully extended leash. $\mathrm{He}$, lying on his side on the floor, appears to have closed his eyes as if to avoid seeing his own humiliation. The Iraqi soldier seems speechless, without language, response-less. Yet he is naked-and ashamed. His legs are bent at the hip and knee, as if to shield prying eyes from his naked genitals. He extends his right hand toward the floor to protect his head. These are clearly human gestures, meaningful responses to cruel and demeaning treatment at the hands of another.

These images figure "us" versus "them" as "man" versus "animal"- but how successfully? Aren't "we" contaminated by "them?" 15 What do we make of the fact that a female American soldier holds the leash? She, too, is a liminal figure who crosses gender lines and historical periods recalling the sahibs of the colonial period who "civilized the savages" via brutality. She, like the terrorists, is presumably willing to die-and to kill-_in the name of our cause. In rendering the Iraqi soldier less-than-human, doesn't she, too, call into question the border between man and animal? Or, better perhaps, does the mute appeal of the Iraqi soldier's body language evoke the abyssal border between who we like to think we are and what we are all capable of? Recall the psychological studies frequently cited in early press stories about Abu Ghraib that demonstrated that, placed in positions of powerover, most subjects would administer electric shocks to the subjected. In which case, how apt is it to name one side of the border "animal" and the other "man?" Where is this border, really, and what does it displace or disavow? 


\section{Human Genetics}

The enormous "progress" made in recent years in mapping the human genome is indeed staggering. The popular press trumpets the possibility of gene therapies to overcome diseases connected to particular links in our DNA. No doubt, this utopic vision perpetuates the modern desire for mastery over our bodies, over death and disease. It has a dystopic counterpart: new forms of Frankenstein lurk in the background (the specters of designer genetics and cloning). But other dynamics appear beneath the surface. On the one hand, the resurgence of religious rejections of evolution some 150 years after the Scopes trial signal ongoing anxiety about linking man too closely to animal. But I also suspect there is another side to this anxiety. In recent years, the announcements of the discovery of a "gay gene" and now of a "God gene" have made headlines. Read beyond the headlines and you discover how misleading they are: there is no "gene" that determines homosexuality or religious faith. Talk to any geneticist and you will learn that genes rarely, in and of themselves, determine anything. The relationship between genetics and environment, nature and nurture, is not unidirectional; it may not even be linear. ${ }^{16} \mathrm{But}$ what is of interest to me here are the reasons why we so want to believe that it might be. Is this the manifestation of a deep desire to, as it were, "return to nature?" A desire, perhaps, for relief from the burden of responsibility that comes with the modern notion of the subject as master of all he surveys? A desire, perhaps, to melt invisibly back into "nature," to disappear across the border between man and animal? An embrace of impouvoir that relieves us of respons-ibility and respons-ability? ${ }^{17}$

\section{The Life of Animals and Hum-animals}

I mentioned the plethora of books attempting to describe for us dense humans the mores, as it were, of our animal familiars, dogs and cats. While both have been the subject of nonfiction essays, a seemingly endless supply of little gift books, and of objets of various sorts (my favorite is the welcome mat that portrays the world from the cat perspective by sneaking a page out of its prison diary). ${ }^{18}$ This body of literature attempts the impossible: it both evokes and attempts to cross the abyssal border between man and animal. It attempts to describe for us a sensibility and a social organization that differs significantly from our own, yet doing so relies on a logic of resemblance and 
reflection, if only to say "is not" to our "is." This literary phenomenon is of a piece with the compassionate response to animality that Derrida described for us as symptomatic of the tectonic shift, though deployed through a modern strategy (epistemological mastery). In this body of literature, the boundary between man and animal shimmers like a mirage- -at once abyssal and elusive, yet bridgeable and breachable.

And then there are the humanimals (my term). What of these people who undergo extreme body modifications (tattooing, piercing, implantation, tongue surgeries) in order to become, as much as possible, the animal they want to be? The documentary I mentioned suggests no single root to this desire: in some cases, relief from the demands of being human; in others, desire for self-making beyond traditional boundaries. Two of the humanimals in the documentary make their livings through displaying their body modifications and performances based on them. But other humanimals live private lives (the cat-man pictured on the webpage describing the documentary, for example, runs a computer repair business out of his home). These humanimals have adopted a hybrid lifestyle whose liminality invokes and violates the border between man and animal. Humanimals speak and respond. They interact with human society often quite volubly and publically (the Lizardman describes in great detail the body modifications he has undergone). Others consider their boundary crossings much more private matters (the cat-man/computer programmer claims deep intuitive connections to the animals he mimics). Humanimals, like genetics, manifest the border between man and animal as more-thanmere words. It materializes and disappears again before our eyes: what is the difference between animal skin and tattooed human skin? Between forked and unforked tongues?

\section{Conclusions}

I promised some remarks on what these signs and wonders suggest about our relationship to l'animot. First, certain aspects of these images suggest that the episteme of l'animot is not yet behind us. Each of these images requires l'animot to be legible. Some of them depict the deliberate deployment of l'animot by man, though often with consequences that he cannot foresee or control. However, each image also demonstrates the liminality-the hymen-like quality-of the border-between. Like it or not, the border seems ever more difficult to police, much less secure. So also the border between modernity and 


\section{ELLEN T. ARMOUR}

not only what will follow it, but what preceded it. Epochal borders, too, can obscure continuities as much as they illumine shifts. Not only does l'animot predate modernity, but the work of Gilles Deleuze and Felix Guattari and Giorgio Agamben demonstrate that fantastical and phantasmatic crossings of the boundary between man and animal predate us. ${ }^{19}$ Hence, we are right to resist understanding postmodernity as the radically new or as the definitive demise of what came before. The war images, for example, caution against simplistic proclamations of the death of the subject. The conventions of mastery and otherness remain all too ready to hand and their inherent violence easy to tap.

Derrida's views on this subject as expressed in a 1981 interview are worth repeating here: "I do not at all believe in what today is so easily called the death of philosophy (nor, moreover, in the simple death of whatever-the book, man, or god, especially since as we all know, what is dead wields a very specific power). ${ }^{.20} \mathrm{I}$ do not mean to suggest that there is no difference between our present and our past on the matter of l'animot. Of note is the distinctive role that new technologies play in all three sets of images that I named as signposts. The Abu Ghraib photographs are, at first glance, the casual souvenir shapshots of a soldier. However, Susan Sontag argues that the digital medium of these photographs make them "less objects to be saved than messages to be disseminated....Where once photographing war was the province of photojournalists, now the soldiers themselves are all photographers-recording their war, their fun, their observations of what they find picturesque, their atrocities - and swapping images among themselves and e-mailing them around the globe."21 The advent of digital photography with its ease of transmission makes every soldier an amateur photojournalist and renders censorship virtually impossible. Whatever similarities the Lizardman may have with Alexis the Trotter (a nineteenth-century Frenchman cited by Deleuze and Guattari who gained notoriety for attempting as much as possible to "be" a horse), the technologies of body modification available to aspiring humanimals now far exceed those available to Alexis. We take for granted a degree of body malleability that is, I think, unprecedented-with effects on our sense of subjectivity that need to be taken into account ${ }^{22}$ Genetic technologies are still in their infancy, but it seems clear that the advent of genetic science has also altered our sense of subjectivity. What all of this portends for the future is impossible to say, but Giorgio Agamben, at least, believes the stakes are high. He writes: 


\section{'MAN' AND HIS 'O'THERS'}

Perhaps not only theology and philosophy but also politics, ethics, and jurisprudence are drawn and suspended in the difference between man and animal. The cognitive experiment at issue in this difference ultimately concerns the nature of man-or more precisely, the production and definition of this nature; it is an experiment de bominis natura. When the difference vanishes and the two terms collapse upon each other-as seems to be happening today - the difference between being and the nothing, licit and illicit, divine and demonic also fades away, and in its place something appears for which we seem to lack even a name. ${ }^{23}$

My reading of the signs and wonders that have been my focus here stops short of Agamben's apocalyptic conclusions. However, I think he accurately identifies the depth and breadth of l'animot's reach and the abyss that opens at its end. How we will come to terms with that end-if indeed that is what we face-only time will tell.

Rhodes College

\section{Notes}

${ }^{1}$ I am referring to Sarah Gualtieri's paper, "Imagining an Arab Race: U.S. Census Classification and Comunity Identity," which was presented at a panel on "How Race Counts: Arabs, Muslims and the Politics of Visibility in the Diaspora" at the annual meeting of the Society for Phenomenology and Existential Pbilosopby [SPEP], Memphis, Tennessee, 30 October 2004. 2004), 62-72.

${ }^{2}$ See Jeffrey Kluger, "The God Gene," Time, Vol. 164, No. 17 (25 October

${ }^{3}$ Gena Kolata, "Beating Hurdles, Scientists Clone a Dog for a First," New York Times, 4 August 2005. 'The dog, an Afghan hound named "Snuppy" (South Korean National University Puppy) was birthed by its surrogate mother, a Golden retriever. The article itself offers an intriguing glimpse into the various permutations of the line between man and animal. Dogs are more difficult to clone than virtually any other animal (including humans) for a number of reasons (complex genetic makeup, previously unpredictable ovulation cycles, etc.). The scientists claim a humanitarian aim in pursuing dog cloning: the cloned dogs could be used for medical research. In support, the author notes that the discovery of insulin and the advent of open heart surgery, for example, were the result of experiments with dogs. A critic of the project, bioethicist Nigel Cameron of the Chicago-Kent College of Law, sees dog cloning as a "dry run for the human cloning debate" because dogs 


\section{ELLEN T. ARMOUR}

are considered by many to be part of the family. Two ironic asides: an American company, Genetic Savings and Clone of Sausalito, CA has been trying for 7 years to clone a dog (apparently envisioning a business in the cloning of family pets). No luck yet, but they just opened a branch (!) in Madison, WI. The e-version of the article featured an ad for a new show on the history channel, "Ape to Man," in which an exasperated chimp says to the man sharing his park bench and bragging about how far back "man" goes, "This is about evolution again isn't it? I've just got two words for you: missing link. Found it yet??" and grins. Both are wearing identical business suits and ties and the chimp is reading the newspaper.

${ }^{4}$ Two examples from the New York Times bestseller lists in recent years are Elizabeth Marshall Thomas' non-fiction book The Hidden Life of Dogs (New York: Houghton Mifflin, 1993) and Paul Auster's novel Timbuktu (New York: Picador Books, 1999), which is told from the perspective (using omniscient narration) of a dog recalling his life with his first owner, a homeless man, as he searches for a new home.

${ }^{5}$ There is now a magazine for dog owners called "Bark" that offers excellent articles on understanding your dog (a non-anthropomorphizing move) surrounded by ads for doggie clothing and gourmet items of various sorts-an interesting juxtaposition.

"The program was "Animal Imitators," NHNZ Production Company, Steven R. Tally and Sandra Gregory, executive producers. For a synopsis, see $<$ bttp:/ wnw. offthefence.com/ content/programme. php?ID=149 $\%$ Categories $=4>$. Some of the humanimals (all sideshow or circus performers) featured on the program have websites. See, for example, the Lizardman (<bttp:/ / bmeworld.com) amago/ $>$ ), and Enigma (tattooed in a jigsaw puzzle motif) and his wife, Katzen, a tattoo artist herself whose body is tattooed to look like a cat (see <bttp:// tattoos.com/ katzen.htm> and <http://tattoos.com/enigma.html >; for pictures, see <bttp: / / wnnw.prickmag.net/enigmafeature.btm〉).

${ }^{7}$ Jacques Derrida, "The animal that therefore I am (more to follow)," Critical Inquiry 28.2 (2002): 369-418; "L'animal que donc je suis (à suivre)," in L'animal autobiographique: Autour de Jacques Derrida, ed. Marie-Louise Mallet (Paris: Galilee, 1999): 251-301. Page references (to the English translation) are hereafter included in the text.

${ }^{8}$ See Giorgio Agamben, The Open: Man and Animal (Stanford, Calif.: Stanford University Press, 2004).

9 The first story features God speaking the world into being in seven days culminating with the creation of human beings (Genesis 1:1-2:3). The second story (Genesis 2:4-3.24) takes place in the Garden of Eden and centers on the creation and fall (according to Christian tradition) of humankind.

${ }^{10}$ This is a place where other poles of the fourfold appear; in this case, man's sexual and divine others. We tend to think of "adam" as a masculine proper name (indeed, it has become one in English). However, the term 
means "human being" in Hebrew. As Phyllis Trible and other commentators have noted, sexual differentiation does not occur in this second story until God makes the woman out of 'adam's rib. The terminology changes at this point to ish (man or husband) and ishab (woman or wife). Trible translates 'adam as "earth creature" to capture both 'adam's sexual neutrality and the connection to 'adamah, Hebrew for dirt, out of which God makes 'adam. See Phyllis Trible, God and the Rhetoric of Sexuality (Philadelphia: Augsburg Fortress Press, 1978).

${ }^{11}$ Emmanuel Levinas, Totality and Infinity: An Essay on Exteriority, transl. Alphonso Lingis (Pittsburgh: Dusquesne University Press, 1969), 21.

${ }^{12}$ Judith Butler, "Violence, Mourning, Politics," in Precarious Life: The Powers of Mourning and Violence (New York: Verso Books, 2004), 19-49.

${ }^{13}$ See my Deconstruction, Feminist Theology, and the Problem of Difference: Subverting the Race/Gender Divide (Chicago: University of Chicago Press, 1999), 156-63 and 169-74.

${ }^{14}$ The photo is available many places on the Web. Perhaps since it was originally published in print by the Washington Post, the copy at their website is the clearest. See "More Prison Photos" in the sidebar at <bttp:// wnnv.washingtonpost.com/wp-srv/world/iraq/ abughraib swornstatements042104.btm〉

${ }^{15}$ One of the soldiers in the 1972 documentary, "Winter Soldier," describes his participation in torturing Vietnamese enemy combatants in exactly these terms, according to a story on Morning Edition. The unidentified veteran notes that, out of fear, he turned the enemy into animals and, in the process, turned himself into an animal, too. John Kalish, "Winter Soldier, A Remembrance of Vietnam Atrocities," Morning Edition, NPR, 15 August 2005.

${ }^{16}$ 'The scientists who have cloned animals report that the clones' personalities and behaviors differ from those of the originals, for example, evidence of the complex and poorly understood relationship between genetics and environment.

${ }^{17}$ DNA has become a tool used to trace genealogy, intriguingly by African Americans in search of more information about both the African and the European/Euro-American sides of their ancestry. Results are mixed, both in content and effect. They are more reliable for near generations, but white relatives are sometimes resistant to acknowledging the genetic connection. Results are less reliable for determining fully the African roots because of a relative paucity in the database, but some African Americans feel drawn to help their newly identified genetic kin in some way. See Amy Harmon, "Blacks Pin Hope on DNA to Fill Slavery's Gaps in Family Trees," in New York Times, 25 June 2005.

${ }^{18}$ In addition to Timbuktu, see Kirsten Bakis' Lives of the Monster Dogs (New York: Warner Books, 1998), which envisions what happens to dogs who, through a scientific experiment worthy of Dr. Frankenstein, gain the ability to talk and walk on two legs. For a sample of some of the variety of 


\section{ELLEN T. ARMOUR}

non-fictional perspectives, see the collection compiled by the editors of Bark magazine entitled Dog is My Co-Pilot: Great Writers on the World's Oldest Friendship (Three Rivers Press, 2004). Of course, a number of the non-fiction books are training manuals, but these too often come in the form of seeking to understand the way dogs think and communicate. Pet owners who happen to be writers have tried their hand at non-fiction accounts of dog-think. Terry Bain, You Are a Dog: Life Through the Eyes of Man's Best Friend (New York: Harmony, 2004) is an example. More frequent are memoirs written by dog owners. Literary scholar Marjorie Garber has gotten into the act with her book, Dog Love (New York: 'Touchstone Books, 1997). Willie Morris' My Dog Skip (New York: Random House, 1995) became a motion picture and was followed by his memoir My Cat Spit MoGee, Morris' account of his reluctant entry late in life (the book was published posthumously, as I recall) into the world of cat ownership. In the same vein, journalist Emily Yoffe's What the Dog Did: Tales From a Formerly Reluctant Dog Owner (New York: Bloomsbury Books, 2005) is a humorous look at the pleasures and pains of life with dogs. Finally, Sara Swan Miller has written a series of books (of very short stories, apparently) that you can read to your dog (or cat)! See her Three Stories You Can Read to Your Dog (New York: Houghton Mifflin, 1997) and Three Stories You Can Read to Your Cat (New York: Houghton Mifflin, 1997) and their sequels.

${ }^{19}$ See Gilles Deleuze and Felix Guattari, A Thousand Plateaus: Capitalism and Schizophrenia, trans. Brian Massumi (Minneapolis: University of Minnesota Press, 1987) and Agamben, The Open. I have only begun to consider humanimals in light of Deleuze and Guattari's work on becoming-animal, a type of boundary-crossing that they propose as provoking new becomings. They cite examples from modern European history of becoming-animal (including two of Freud's famous case histories, the Wolf Man and Little Hans) that would need to be considered alongside the humanimals that I discuss here. Agamben's small book traces the shifting border between man and animal in the transition from medieval to modern and beyond. As he notes, medieval taxonomies of nature included fantastic half-human/halfanimal beasts whose existence was presumed to be at least as real as lions, tigers, and bears (oh, my).

${ }^{20}$ Jacques Derrida, "Implications: Interview with Henti Ronse" in Positions, trans. Alan Bass (Chicago: University of Chicago Press, 1981), 6.

${ }^{21}$ Susan Sontag, "Regarding the Torture of Others," in New York Times Magazine, 23 May 2004, 27. She notes that the Abu Ghraib photos differ from souvenir war photography from World War II. German soldiers frequently photographed their atrocities, but rarely posed with their victims. The closest analogue to the Abu Ghraib photographs, Sontag suggests, are lynching photographs, which were taken as "trophies." Dora Apel offers a substantive and sophisticated comparison of the Abu Ghraib photos with lynching photos that considers not only content and form but their cultural significance and 


\section{'MAN' AND HIS 'OTHERS'}

political effects. See her "Torture Culture: Lynching Photographs and the Images of Abu Ghraib," in The Art Journal, Vol. 64, No. 2 (Summer 2005), 88100.

${ }^{22}$ Here too, shadows of another pole of the fourfold appear in the form of cosmetic plastic surgeries (à la "Extreme Makeover") and sexual reassignment surgeries. The relationships between these medical procedures and past and present regimes of sex and gender are, to say the least, hardly straightforward.

${ }^{23}$ Agamben, The Open, 22. 